\title{
The Azygos Vein: to Resect or Not?
}

\author{
Judith Boone $\cdot$ Richard van Hillegersberg
}

Received: 5 May 2008 / Accepted: 9 May 2008 / Published online: 2 August 2008

(C) 2008 The Author(s)

\section{Dear Editor,}

With great interest we read the article by Schröder et al. to be published in a forthcoming issue of the Journal of Gastrointestinal Surgery in which they investigated the potential value of resecting the azygos vein in transthoracic esophagectomy for esophageal cancer. ${ }^{1}$

During (robot-assisted) thoracoscopic esophagectomy, the trunk of the azygos vein is often preserved as the scopic ligation of the numerous intercostal veins is technically difficult and time-consuming. ${ }^{2-6}$ One may postulate that this may negatively affect the extent of lymph node harvesting or the circumferential radical (R0) resection rate.

Schröder et al. have, therefore, performed a prospective evaluation on the amount of lymph nodes surrounding the azygos vein in 92 patients with esophageal cancer having undergone open transthoracic esophagectomy with two-field lymphadenectomy. ${ }^{1}$ Lymph nodes near the azygos vein were identified in $65 \%$ of patients and metastases in these lymph nodes were found in $8 \%$. They, therefore, conclude that the dissection of the azygos vein should not be abandoned, irrespective of the surgical approach.

A comment should be made on the design of the study. As clearly shown in Figure 2 of their article, they dissected the azygos vein with the surrounding tissues

J. Boone $(\varangle) \cdot$ R. van Hillegersberg

Department of Surgery (G04.228),

University Medical Center Utrecht,

Heidelbergaan 100 ,

3584 CX Utrecht, The Netherlands

e-mail: jboone2@umcutrecht.nl

e-mail: judithboone@hotmail.com sharply from the esophagus, which is not representative for (robot-assisted) thoracoscopic esophagectomy. In (robot-assisted) thoracoscopic esophagectomy, subsequent to the ligation of the azygos arch, the mediastinal dissection of the esophagus and surrounding tissues is performed sharply along the azygos trunk. In this way, the fatty tissue in between the esophagus and the azygos vein (including the lymph nodes of stations 108 and 110) as well as the thoracic duct are included in the esophageal resected specimen and are not left in situ when the trunk of the azygos vein is preserved. ${ }^{2}$ The number of lymph nodes that will be left in situ with (robot-assisted) thoracoscopic esophagectomy will, therefore, be much less than stated in this article. Indeed, in our recently published cadaveric study in which we investigated an identical research question, a mean amount of only 0.67 lymph nodes were identified around the azygos vein using the thoracoscopic dissection method. ${ }^{7}$ Using this approach, in $60 \%$ of cadavers, no lymph nodes near the azygos vein were detected at all. With regard to the possible effect of azygos vein preservation on the radical resection rate, we can refer to our first report on 21 esophageal cancer patients having undergone robot-assisted thoracoscopic esophagectomy. The $\mathrm{R} 0$ resection rate of $76 \%$ in that series is similar to that of open transthoracic esophagectomy. ${ }^{2,8}$ In our opinion, it is, therefore, justified to preserve the azygos trunk during (minimally invasive) transthoracic esophagectomy.

Open Access This article is distributed under the terms of the Creative Commons Attribution Noncommercial License which permits any noncommercial use, distribution, and reproduction in any medium, provided the original author(s) and source are credited. 


\section{References}

1. Schröder W, Vallbohmer D, Bludau M, Banczyk A, Gutschow C, Holscher AH. The resection of the azygos vein-necessary or redundant extension of transthoracic esophagectomy? J Gastrointest Surg 2008;12:1163-1167. doi:10.1007/s11605-008-0487-x.

2. van Hillegersberg R, Boone J, Draaisma WA, Broeders IA, Giezeman MJ, Borel Rinkes IH. First experience with robotassisted thoracoscopic esophagolymphadenectomy for esophageal cancer. Surg Endosc 2006;20:1435-1439. doi:10.1007/s00464-0050674-8.

3. Luketich JD, Alvelo-Rivera M, Buenaventura PO, Christie NA, MacCaughan JS, Little VR, et al. Minimally invasive esophagectomy: outcomes in 222 patients. Ann Surg 2003;238:486-494.

4. Nguyen NT, Roberts P, Follette DM, Rivers R, Wolfe BM. Thoracoscopic and laparoscopic esophagectomy for benign and malignant disease: lessons learned from 46 consecutive procedures.
J Am Coll Surg 2003;197:902-913. doi:10.1016/j.jamcollsurg. 2003.07.005.

5. Osugi H, Takemura M, Higashino M, Takada N, Lee S, Ueno M, et al. Video-assisted thoracoscopic esophagectomy and radical lymph node dissection for esophageal cancer. A series of 75 cases. Surg Endosc 2002;16:1588-1593. doi:10.1007/s00464-002-9019-z.

6. Watson DI, Davies N, Jamieson GG. Totally endoscopic Ivor Lewis esophagectomy. Surg Endosc 1999;13:293-297. doi:10.1007/ s004649900969.

7. Boone J, Schipper MEI, Bleys RLAW, Borel Rinkes IHM, van Hillegersberg R. The effect of azygos vein preservation on mediastinal lymph node harvesting in thoracic esophagolymphadenectomy. Dis Esophagus 2008;21:226-229. doi:10.1111/j.14422050.2007.00760.x.

8. Hulscher JB, van Sandick JW, de Boer AG, Wijnhoven BP, Tijssen JG, Fockens P, et al. Extended transthoracic resection compared with limited transhiatal resection for adenocarcinoma of the esophagus. $\mathrm{N}$ Engl J Med 2002;347:1662-1669. doi:10.1056/NEJMoa022343. 